\title{
IDENTYFIKACJA BRONI PALNEJ NA PODSTAWIE SYGNAŁÓW AKUSTYCZNYCH
}

\begin{abstract}
W artykule przedstawiono wstępne wyniki analizy sygnałów akustycznych emitowanych przez wybrane typy broni. Przedstawiona w opracowaniu część wyników przeprowadzonych badań dotyczy fazy przygotowania broni do strzału. Pomiary akustyczne zrealizowano $\mathrm{z}$ zastosowaniem analizatora dźwięku firmy Bruel\&Kjaer 2260 Investigator wraz z dwumikrofonową sondą natężenia dźwięku B\&K 3595 oraz szerokopasmowego analizatora cyfrowego DSO-2902.
\end{abstract}

Słowa kluczowe: emisja dźwięku, identyfikacja rodzaju broni palnej, pomiary sygnałów akustycznych

\section{Wprowadzenie}

Analiza sygnałów akustycznych w ostatnich latach zyskuje coraz większą popularność. Każdy z nas, kupując urządzenie mechaniczne, może zauważyć dane dotyczące poziomu emisji dźwięku emitowanego przez to urządzenie, co jest szczególnie eksponowane w urządzeniach o podwyższonym jego poziomie lub do pracy $\mathrm{w}$ warunkach wewnątrzlokalowych. Wiąże się to nie tylko z ochroną narządu słuchu organizmu ludzkiego (długotrwała ekspozycja na odpowiednio wysokie poziomy może prowadzić, i z reguły prowadzi, do trwałych uszkodzeń), ale również z poziomem komfortu mieszkalnego osób dokonujących zakupu urządzeń. Rozwój systemów pomiarowych pod koniec lat 90. umożliwił także skonstruowanie przenośnych analizatorów umożliwiających lokalizację głównych źródeł dźwięku z wykorzystaniem energetycznych metod pomiarowych, co w sposób znaczący pozwala inżynierom na ograniczenie emisji dźwięku przez zmiany konstrukcyjne czy też zastosowanie izolacji absorbujących fale akustyczne. Każde pracujące urządzenie charakteryzuje się niepowtarzalną barwą dźwięku o odpowiednim zakresie częstotliwości i natężeniu. Na podstawie fal

\footnotetext{
${ }^{1}$ Autor do korespondencji/corresponding author: Leszek Chałko, Uniwersytet Technologiczno-Humanistyczny w Radomiu, ul. Stasieckiego 54, 26-600 Radom, tel.: 48 3617676, e-mail: leszek. chalko@uthrad.pl

${ }^{2}$ Paweł Maciąg, Uniwersytet Technologiczno-Humanistyczny w Radomiu, e-mail: p.maciag @ uthrad.pl
} 
akustycznych rozpoznajemy pracujące maszyny, urządzenia, pojazdy czy nawet kroki znanych nam osób.

Autorzy artykułu postanowili zająć się tematyką analizy sygnałów akustycznych w celu identyfikacji rodzaju i typu broni palnej. Obecnie na świecie istnieją systemy montowane na pojazdach bojowych, wskazujące kierunek, z którego zostały oddane strzały. Nie jest jednak znany żaden system identyfikacji użytej broni. Mimo że w naszym kraju, jak wykazują statystyki, liczba przestępstw $\mathrm{z}$ użyciem broni palnej wykazuje tendencję spadkową [1], budowa takiego systemu byłaby niezwykle przydatnym elementem dla służb podległych MON. Oprócz coraz bardziej rozwiniętego systemu monitoringu wizyjnego dość istotnym elementem wydaje się rozwój monitoringu akustycznego. Każde zdarzenie dotyczące zagrożenia utraty zdrowia lub życia charakteryzuje się określoną emisją fal dźwiękowych, które po odpowiedniej obróbce stałyby się podstawą do określenia na przykład rodzaju i typu użytej broni. Systemy takie mogłyby stanowić nie tylko urządzenia stacjonarne, lecz także mobilne przeznaczone dla służb państwowych podległych MON.

Autorzy niniejszego artykułu przedstawili wyniki wstępnych, bardzo szeroko zakrojonych badań dotyczących emisji dźwięku broni palnej, obejmujących pomiary sygnałów akustycznych emitowanych podczas przeładowania szkolnych egzemplarzy karabinka AKM, PPSz i pistoletu P-83. Po wstępnej analizie uzyskanych wyników nastąpią dalsze badania różnych typów i rodzajów broni w warunkach strzelnic zakładów produkcyjnych (Radomska Fabryka Broni), jak również w warunkach poligonowych. Pomiar emisji dźwięku był realizowany w laboratoriach UTH Radom za pomocą analizatora Brüel\&Kjaer 2260 Investigator wyposażonego $\mathrm{w}$ dwumikrofonową sondę pomiaru natężenia dźwięku $\mathrm{B} \& \mathrm{~K}$ 3595. Sygnały analogowe dźwięku rejestrowano także z zastosowaniem cyfrowego oscyloskopu DSO-2902 i kamery Heanworld HD2M256.

\section{Pomiary dźwięku w polu akustycznym}

Badania źródeł emisji dźwięku zależą od warunków fizycznych, w jakich są dokonywane. Do każdych z nich powinna zostać dobrana odpowiednia metoda pomiarowa. Badania akustyczne prowadzone w pomieszczeniach zamkniętych o dużej liczbie fal odbitych różnią się znacząco od badań prowadzonych na zewnątrz budynków. Dobór odpowiedniej metody rejestracji danych i konfiguracji wykorzystywanego sprzętu w stopniu znaczącym pozwala na uniknięcie błędów. Pomiary emisji dźwięku wykonane w pomieszczeniach zamkniętych wymagają prawidłowego określenia warunków akustycznych, dobrania do nich odpowiedniej metody, jak również samego sprzętu. Decyduje o tym wiele czynników, takich jak: wymiary fizyczne obiektu badań, wymiary pomieszczenia, w którym się znajduje źródło dźwięku, szum otoczenia, siła wiatru, wreszcie temperatura i wilgotność powietrza. Warunki panujące w pomieszczeniach rzeczywistych są odle- 
głe od właściwości akustycznych panujących w komorach bezechowych czy pogłosowych. Komora bezechowa to pomieszczenie, którego wszystkie powierzchnie są wyłożone materiałem silnie dźwiękochłonnym, eliminującym odbicia. Komory pogłosowe zaś, w przeciwieństwie do poprzednio wspomnianych, mają powierzchnie maksymalnie odbijające i nierównoległe względem siebie, w wyniku czego cała energia dźwięku zostaje rozłożona, tworząc pole rozproszone [2].

Większość mierników emisji dźwięku jest wyposażona w mikrofony pola swobodnego i w tym właśnie zakresie powinno się dokonywać pomiarów poziomu ciśnienia dźwięku. Rysunek 1. pokazuje w sposób schematyczny warunki akustyczne pomieszczeń.

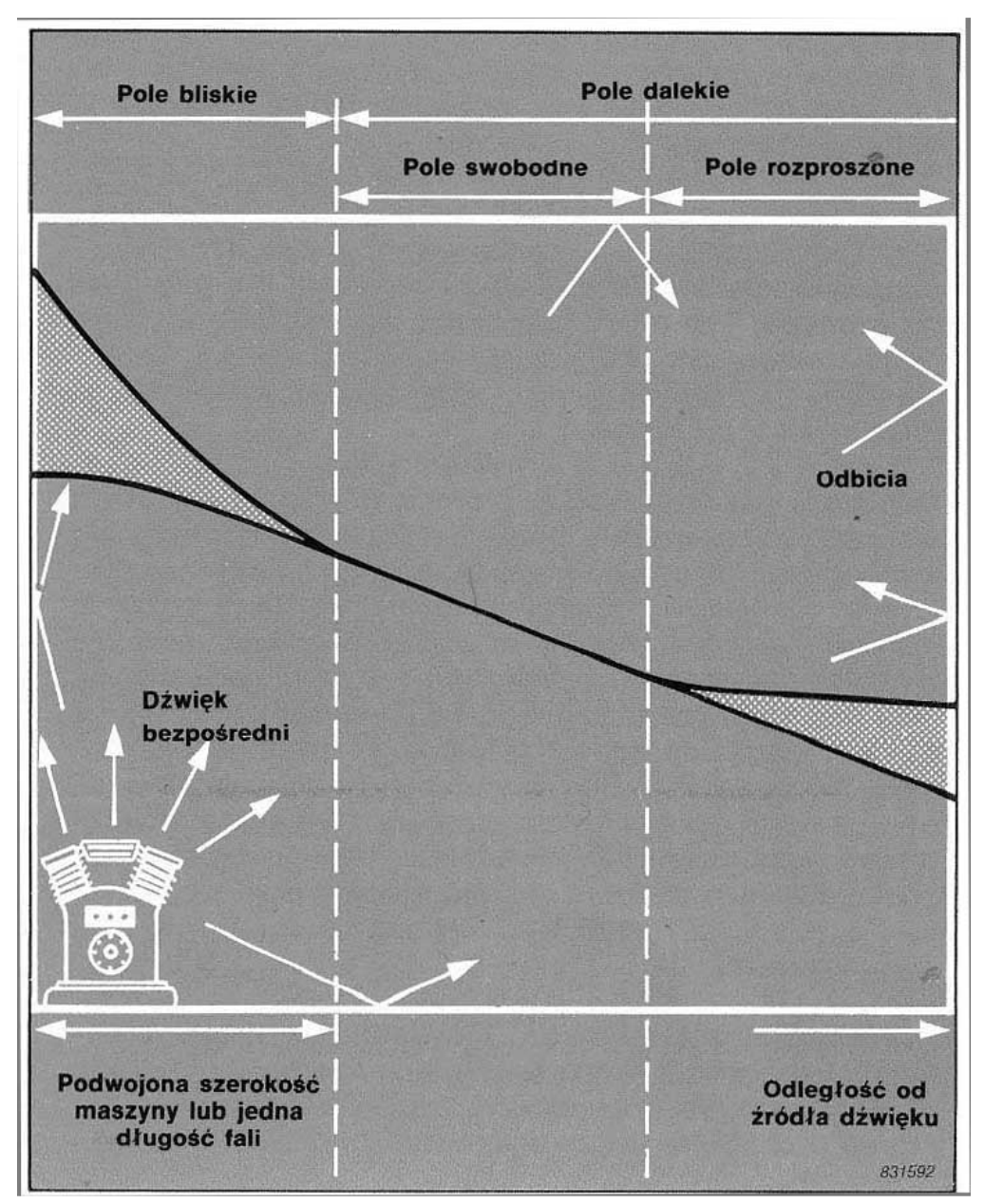

Rys. 1. Warunki akustyczne w pomieszczeniach zamkniętych

Fig. 1. Acoustic conditions in enclosed spaces 
Umieszczenie miernika zbyt blisko maszyny będącej źródłem dźwięku powoduje, że nawet niewielkie zmiany jego pozycji prowadzą do znacznych różnic w wynikach pomiaru poziomu dźwięku. Zjawisko to ma miejsce wówczas, gdy odległość jest mniejsza od długości fali najniższej emitowanej częstotliwości, lub gdy jest mniejsza niż podwojony, największy wymiar źródła hałasu. Obszar ten jest nazywany polem bliskim [3]. Normalny zakres częstotliwości dźwięków odbieranych przez młodego, zdrowego człowieka zawiera się w przedziale, w przybliżeniu, od $20 \mathrm{~Hz}$ do $20 \mathrm{kHz}$. Z równania (1) można wyznaczyć długość fali jako funkcję częstotliwości [4]:

$$
\lambda=\frac{c}{f}
$$

gdzie: $\lambda$ - długość fali,

$f$ - częstotliwość drgań,

$c$-prędkość rozprzestrzeniania się drgań akustycznych.

Różnica między ciśnieniem wywołanym drganiami a ciśnieniem statycznym w danym punkcie środowiska jest nazywana ciśnieniem akustycznym. Obszary przestrzeni, w których występują drgania akustyczne powietrza, noszą nazwę pola akustycznego. Jednym z podstawowych parametrów określających stan akustyczny w danym punkcie pola akustycznego jest poziom ciśnienia akustycznego $L_{p}$, określany zależnością:

$$
L_{p}=10 \log \frac{p}{p_{0}}
$$

gdzie: $p$ - skuteczna wartość ciśnienia akustycznego,

$p_{0}$ - skuteczna wartość ciśnienia akustycznego odniesienia równa $2 \cdot 10^{-5} \mathrm{~N} / \mathrm{m}^{2}$.

Pomiar poziomu ciśnienia dźwięku SPL (Sound Pressure Level), powszechnie uważanego za ilość hałasu wydzielanego przez maszynę, określa zmiany wartości ciśnień akustycznych zachodzących w polu swobodnym lub polu rozproszonym. Pole swobodne charakteryzuje się tym, że wartość poziomu ciśnienia dźwięku mierzonego przez mikrofon skierowany na źródło dźwięku spada o wartość $6 \mathrm{~dB}$ wraz z dwukrotnym zwiększeniem odległości od źródła hałasu [3]. Możliwe są także pomiary akustyczne w polu bliskim źródła dźwięku, wymagają one jednak zastosowania energetycznych odpowiedników poziomu ciśnienia dźwięku: jego natężenia i mocy. Natężenie dźwięku $L_{I}$ definiuje się za pomocą następującego wzoru:

$$
L_{I}=10 \log \frac{I}{I_{0}}
$$


gdzie: $I$ - natężenie dźwięku w danym punkcie środowiska, $I_{0}$ - natężenie odniesienia; $I_{0}=1 \mathrm{pW} / \mathrm{m}^{2}$.

Poziom mocy dźwięku danego źródła $L_{w}$ można określić zależnością:

$$
L_{W}=10 \log \frac{W}{W_{0}}
$$

gdzie: $W$ - moc dźwięku danego źródła,

$W_{0}-$ moc odniesienia; $W_{0}=1 \mathrm{pW}$.

Każda z przedstawionych wielkości opisujących stan akustyczny w danym punkcie opiera się na skali logarytmicznej. Jest to naturalne powiązanie z ludzkim odczuciem liniowego przyrostu głośności dźwięku ze wzrostem logarytmu ciśnienia lub intensywności dźwięku (prawo Webera-Fechnera) [5]. Jednym z niewielu urządzeń mogących mierzyć energetyczną postać ciśnienia dźwięku poza laboratorium w warunkach rzeczywistych jest Analizator 2260 Investigator z sondą natężenia typu 3595.

Pomieszczenie wewnętrzne laboratorium, w którym dokonywano pomiarów, nie spełniało ze względu na swoje wymiary wymogów pola swobodnego, czy też rozproszonego. Zdecydowano się zatem na zastosowanie pomiarów akustycznych analizatora firmy Brủel\&Kjaer 2260 Investigator wyposażonego w dwumikrofonową sondę pomiaru natężenia dźwięku B\&K 3595. Analizator oprócz standardowego oprogramowania dla sond jednomikrofonowych miał zainstalowaną aplikację BZ7205, umożliwiającą pomiar mocy dźwięku metodą natężeniową. Wykorzystany system pomiarowy posiada aktualne świadectwo wzorcowania wydane przez akredytowane laboratorium wzorcujące HAIK Sp. z o.o. nr świadectwa: 3290/2017 z 13 grudnia 2017 r. Pełne określenie mocy dźwięku emitowanej przez badane typy broni z tytułu bardzo krótkiego czasu trwania procesu przygotowania do wystrzału nie był możliwy. Autorzy zdecydowali się na pomiar fal akustycznych przez okres $2 \mathrm{~s}$, przyjmując za podstawę powierzchnię pomiarową o wymiarach $0,5 \times 0,5 \mathrm{~m}\left(0,25 \mathrm{~m}^{2}\right)$. Wyniki badań zarejestrowano dla analizy widmowej fal dźwiękowych w pasmach 1/3 oktawy. Użyty $12 \mathrm{~mm}$ dystans oddzielający mikrofony pomiarowe umożliwił rejestrację fal o częstotliwości 25-10 000 $\mathrm{Hz}$, a więc najlepiej odbieranych przez ucho ludzkie. Dodatkowo konfiguracja zastosowanego analizatora umożliwiała dwukanałowy pomiar ciśnienia dźwięku SPL (Sound Pressure Level), który także w celach porównawczych został zarejestrowany. Wszystkie cykle pomiarów wykonano trzykrotnie w celu minimalizacji błędów. Dzięki zastosowanej metodzie można dokonywać pomiarów w polu bliskim maszyny i określać kierunek przepływu energii [6, 7]. Przed każdą serią badań analizator był skalowany kalibratorem B\&K 4231. Widok analizatora, sondy dwumikrofonowej i kalibratora przedstawia rys. 2. Rejestracja emisji dźwięku została dokonana z zastosowaniem cyfrowego oscyloskopu DSO-2902 
$\mathrm{z}$ analogowego toru dźwiękowego kamery monitoringu wizyjnego Heanworld HD2M256. Zastosowanie kamery powszechnego użytku miało udowodnić, że postawione cele można zrealizować na ogólnie stosowanym sprzęcie.

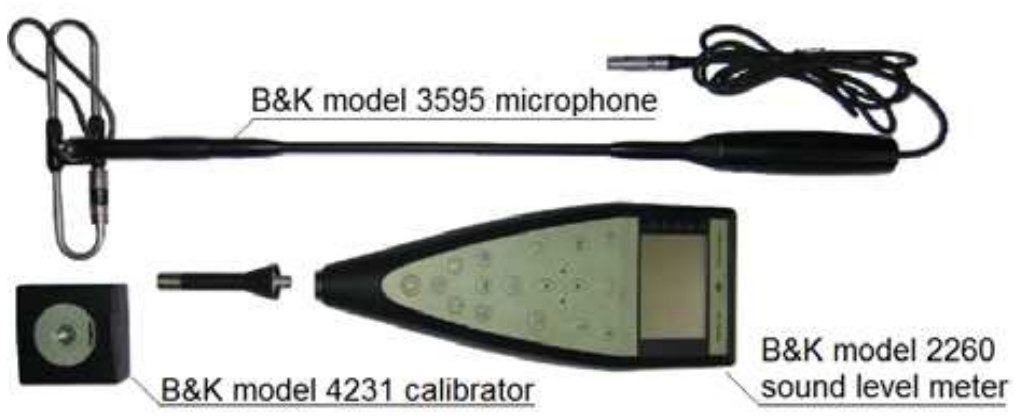

Rys. 2. Widok analizatora 2260 firmy Brüel\&Kjaer z mikrofonami pomiarowymi i kalibratorem

Fig. 2. View of the Brüel\&Kjaer 2260 analyzer with measuring microphones and calibrator

\section{Wyniki pomiarów}

Dane zarejestrowane podczas pomiarów emisji dźwięku z wykorzystaniem analizatora B\&K 2260 Investigator i dwumikrofonowej sondy natężenia dźwięku B\&K 3595 zostały przetworzone do postaci zarówno graficznej, jak i tabelarycznej w celu lepszej interpretacji wyników. Uzyskane zestawienia zostały zaprezentowane osobno dla obu urządzeń pomiarowych. Ze względu na wstępny, rozpoznawczy charakter badań pomiary akustyczne były wykonywane dla wszystkich użytych typów broni w odległości $1,5 \mathrm{~m}$ od emitera dźwięku. Zachowanie tych samych warunków pozwoliło na dość dokładne porównanie poziomów ciśnień emitowanego dźwięku Lp oraz cząstkowych mocy dźwięku Lw. Wyniki analizy spektralnej w pasmach $1 / 3$ przedstawiają wielkości bez ingerencji wynikającej z korekcji krzywymi ważenia typu A - dopasowującymi poszczególne zakresy częstotliwości do percepcji ucha ludzkiego. Na rysunkach 3-5 zestawiono wyniki analizy widmowej dla pasm 1/3 oktawy zarejestrowanych ciśnień dźwięku Lp(L) dla wszystkich trzech użytych typów broni: karabinków AKM i PPSz oraz pistoletu P-83. Tabela 1. zawiera zestawienie zarejestrowanych wyników całkowitych ciśnień dźwięku Lp zarówno dla korekcji krzywą ważenia typu A, jak również bez jej użycia Lin. 
Tabela 1. Zarejestrowane ciśnienia dźwięku

Table 1. Recorded sound pressure

\begin{tabular}{|c|c|c|c|c|c|}
\hline $\begin{array}{l}\text { Numer } \\
\text { pomiaru }\end{array}$ & $\begin{array}{l}\text { Numer mikrofonu } \\
\text { pomiarowego }\end{array}$ & $\begin{array}{c}\text { Korekcja } \\
\text { A - z korekcją } \\
\mathrm{L}-\text { bez korekcji }\end{array}$ & $\begin{array}{l}\text { AKM } \\
\text { Lp } \\
\text { dB }\end{array}$ & $\begin{array}{l}\text { PPSz } \\
\text { Lp } \\
\text { dB }\end{array}$ & $\begin{array}{c}\text { P-83 } \\
\text { Lp } \\
\text { dB }\end{array}$ \\
\hline \multirow{4}{*}{3} & \multirow{2}{*}{ Chanel2 } & A-Total & 88,2 & 77 & 76,3 \\
\hline & & L-Total & 87,3 & 76,5 & 75,9 \\
\hline & \multirow{2}{*}{ Chanel1 } & A-Total & 88 & 77,2 & 76,7 \\
\hline & & L-Total & 87,2 & 76,7 & 76,2 \\
\hline \multirow{4}{*}{2} & \multirow{2}{*}{ Chanel2 } & A-Total & 88,3 & 78,3 & 76,1 \\
\hline & & L-Total & 87,5 & 77,7 & 76,5 \\
\hline & \multirow{2}{*}{ Chanel1 } & A-Total & 88,1 & 78,6 & 76,2 \\
\hline & & L-Total & 87,3 & 78 & 76,6 \\
\hline \multirow{6}{*}{1} & \multirow{2}{*}{ Chanel2 } & A-Total & 88,9 & 77,7 & 76,1 \\
\hline & & L-Total & 88 & 77,3 & 76,1 \\
\hline & \multirow{2}{*}{ Chanel1 } & A-Total & 88,6 & 77,1 & 76,5 \\
\hline & & L-Total & 87,8 & 76,7 & 76,4 \\
\hline & Wartość średnia & A-Total & 88,35 & 77,65 & 76,31 \\
\hline & Wartość średnia & L-Total & 87,51 & 77,15 & 76,28 \\
\hline
\end{tabular}

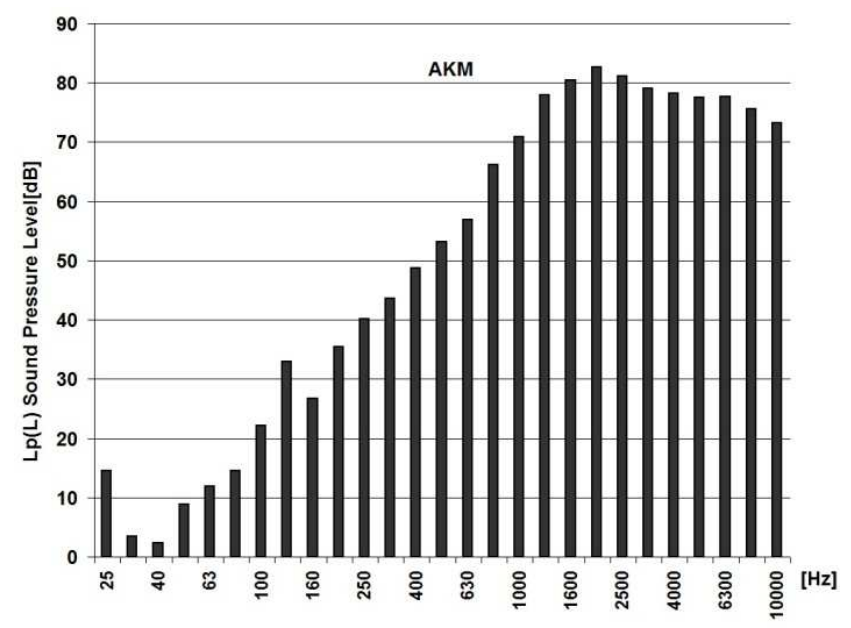

Rys. 3. Analiza widmowa w pasmach $1 / 3$ oktawy ciśnienia dźwięku dla przeładowania karabinka AKM

Fig. 3. Spectral analysis in the $1 / 3$ octave band of sound pressure for overloading the AKM fire-arm 


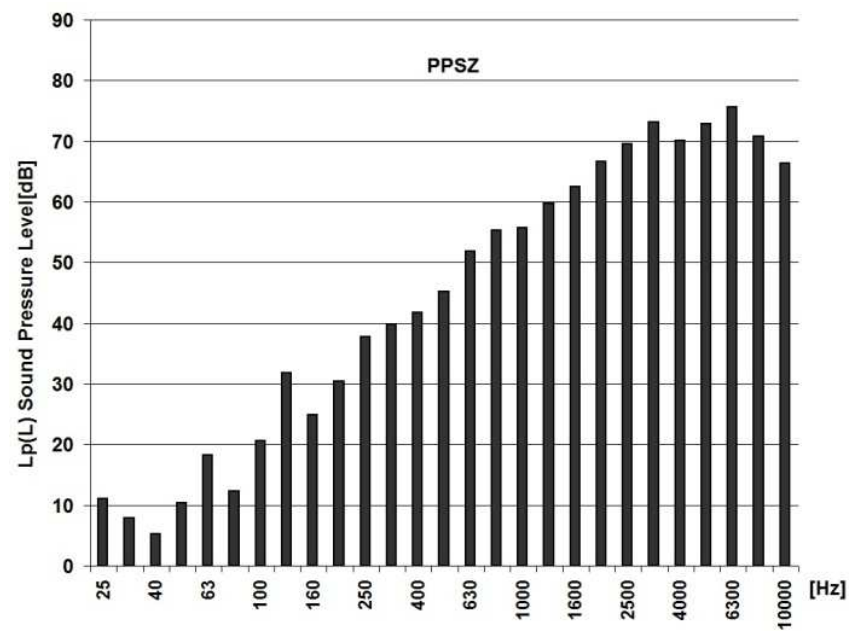

Rys. 4. Analiza widmowa w pasmach 1/3 oktawy ciśnienia dźwięku dla przeładowania karabinka PPSz

Fig. 4. Spectral analysis in the $1 / 3$ octave band of sound pressure for overloading the PPSz fire-arm

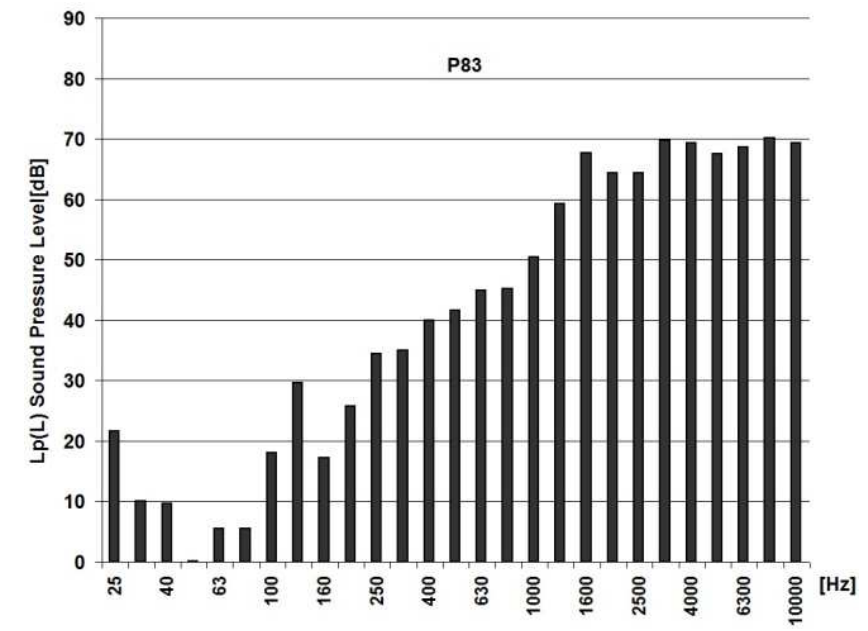

Rys. 5. Analiza widmowa w pasmach 1/3 oktawy ciśnienia dźwięku dla przeładowania pistoletu P-83

Fig. 5. Spectral analysis in the $1 / 3$ octave band of sound pressure for overloading the P-83 fire-arm

Tak jak wspomniano w części wstępnej, zastosowanie dwumikrofonowej sondy natężenia dźwięku umożliwiło pomiar częściowej mocy dźwięku emitowanej przez badane obiekty. Rysunki 6-8 przedstawiają zestawienie wyników ana- 
lizy widmowej dla pasm 1/3 oktawy zarejestrowanych mocy dźwięku Lw(L), a tab. 2. zawiera zarejestrowane wyniki mocy dźwięku Lw w całym analizowanym zakresie częstotliwości - zarówno dla korekcji krzywą ważenia typu A, jak również bez jej użycia Lin.

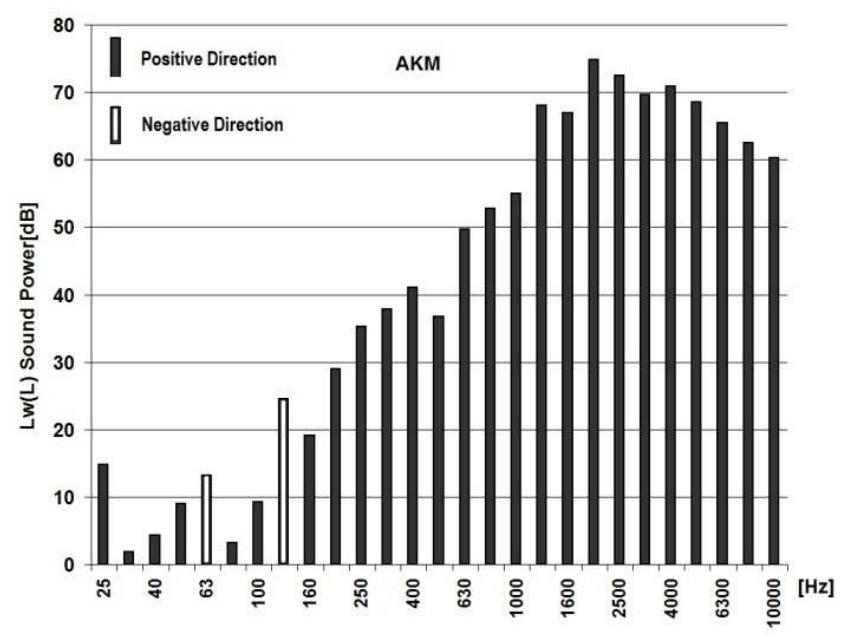

Rys. 6. Analiza widmowa w pasmach $1 / 3$ oktawy mocy dźwięku dla przeładowania karabinka AKM

Fig. 6. Spectral analysis in the $1 / 3$ octave band of sound power for overloading the AKM fire-arm

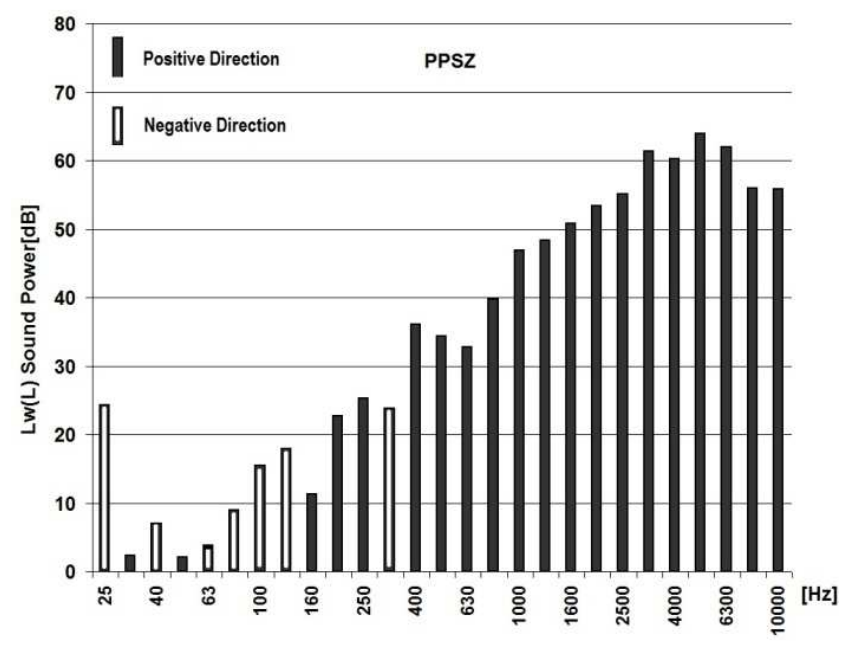

Rys. 7. Analiza widmowa w pasmach $1 / 3$ oktawy mocy dźwięku dla przeładowania karabinka PPSz

Fig. 7. Spectral analysis in the $1 / 3$ octave band of sound power for overloading the PPSz fire-arm 


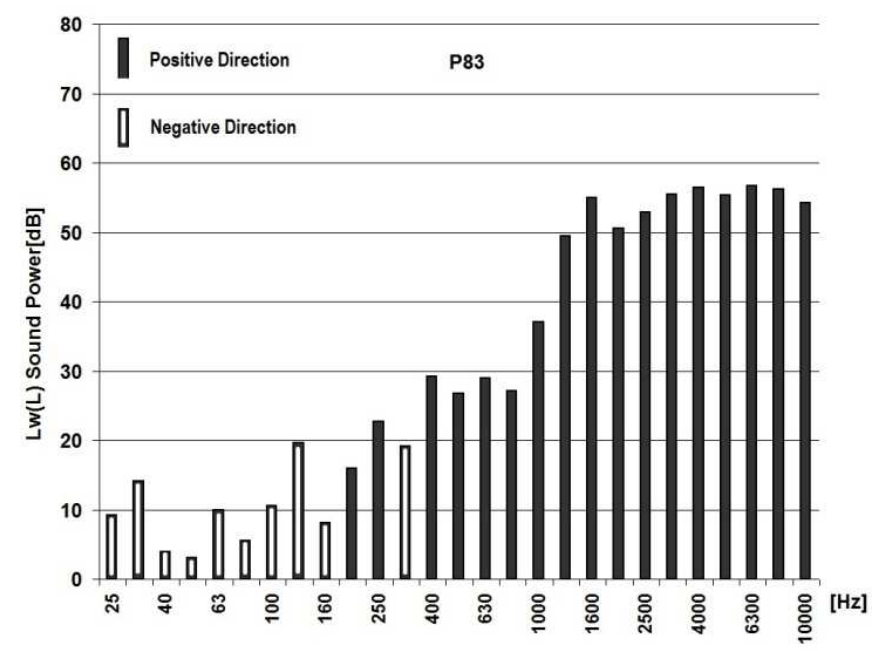

Rys. 8. Analiza widmowa w pasmach $1 / 3$ oktawy mocy dźwięku dla przeładowania pistoletu P-83

Fig. 8. Spectral analysis in the $1 / 3$ octave band of sound power for overloading the P-83 fire-arm

Tabela 2. Zarejestrowane moce dźwięku Lw

Table 2. Recorded sound powers Lw

\begin{tabular}{|c|c|c|c|c|}
\hline \multirow{3}{*}{ Numer pomiaru } & $\begin{array}{c}\text { Korekcja } \\
\text { A - z korekcja } \\
\text { L- bez korekcji }\end{array}$ & $\begin{array}{c}\text { AKM } \\
\text { Lw } \\
\mathrm{dB}\end{array}$ & $\begin{array}{c}\text { PPSz } \\
\text { Lw } \\
\mathrm{dB}\end{array}$ & $\begin{array}{c}\text { P-83 } \\
\text { Lw } \\
\mathrm{dB}\end{array}$ \\
\hline \multirow{2}{*}{3} & A-Total & 79,3 & 67,8 & 66,3 \\
\cline { 2 - 5 } & L-Total & 78,3 & 67,3 & 66 \\
\hline \multirow{2}{*}{2} & A-Total & 79 & 67,2 & 66,6 \\
\cline { 2 - 5 } & L-Total & 78 & 66,7 & 66 \\
\hline \multirow{2}{*}{1} & A-Total & 79,5 & 66,7 & 63,2 \\
\hline Wartość średnia & L-Total & 78,5 & 66,1 & 62,9 \\
\hline Wartość średnia & A-Total & 79,27 & 67,23 & 65,37 \\
\hline
\end{tabular}

Przedstawioną ideę rozpoznawania rodzaju i typu broni można porównać w dużym uproszczeniu z melodią piosenki. Poszczególne dźwięki o określonej częstotliwości i natężeniu są elementami charakterystycznymi dla każdej z nich. Zastosowanie pomiarów odpowiednio podzielonej na pasma analizy widmowej ciśnienia i mocy dźwięku pozwala dość precyzyjnie określić typ broni przez porównanie analizowanych sygnałów $\mathrm{z}$ danymi zarejestrowanymi uprzednio w bazie danych. 
Konstruktor broni, projektując poszczególne elementy oraz dobierając odpowiednie materiały, wpływa na charakterystyczną dla każdej z nich emisję dźwięku. Projektując, ustala kolejność działania mechanizmów. Początek ruchu przeładowania rozłącza mechanizm spustowy, napina kurek, wyciąg wyrywa łuskę, wyrzutnik uderza w dno wystrzelonej łuski, która wyskakując spod pazura, hałasuje, zderzając się z elementami broni. Nowy nabój wyskakuje spod ślizgu zamka i ustawia się gwałtownie w pozycję dosyłania, czemu towarzyszy dodatkowo szum przemieszczającej się w magazynku amunicji. W mechanizmie spustowym zaskakują zaczepy, zamek uderza w tylny ogranicznik i ruch zmienia swój kierunek. Zamek zwalnia nacisk na kurek, kurek staje na zaczepie, zamek wprowadza nabój do komory, zwalnia spust samoczynny/załącza mechanizm spustowy i gwałtownie uderza w łuskę naboju, kończąc tym samym, kilkakrotną oscylacją, ruch do przodu. Jak wspomniano, zdarzeń wywołujących ciche i głośne dźwięki w trakcie pracy mechanizmów broni jest wiele i układają się one w powtarzalną dla danego typu sprzętu melodię, którą w sposób prosty można jednoznacznie zidentyfikować na podstawie analizy oscylogramów zarejestrowanej emisji dźwięku (rys. 9.).
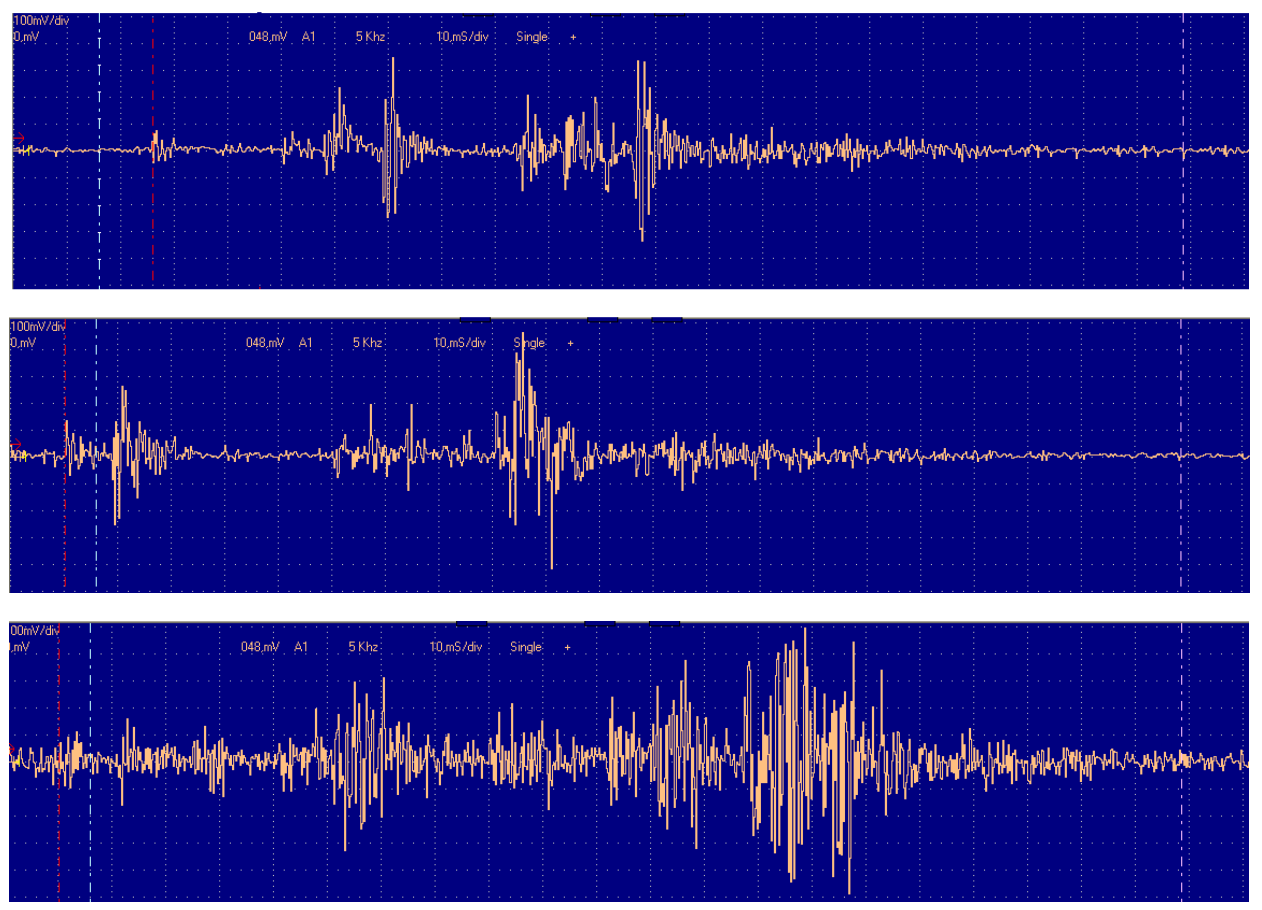

Rys. 9. Oscylogram dźwięku przeładowania pistoletu P-83 (górny), pistoletu PPSz (w środku), karabinu AKM (na dole)

Fig. 9. Oscillogram of the P-83 pistol reload (upper), PMSz pistol (inside), AKM karabiner (bottom) 


\section{Podsumowanie}

Analiza emisji dźwięku wskazuje znaczące różnice pomiędzy poszczególnymi rodzajami wybranych egzemplarzy broni. Podczas przeładowania, jak i strzału każdy element mechanizmu wydaje określony, charakterystyczny dźwięk o odpowiedniej mocy, w określonym zakresie częstotliwości, jak również kolejności i przedziale czasowym. Analiza rys. 5-10 wskazuje, że największym poziomem ciśnienia dźwięku $\mathrm{Lp}(\mathrm{A})=88,3 \mathrm{~dB}$ oraz emitowaną mocą dźwięku $\mathrm{Lw}(\mathrm{A})=79,3 \mathrm{~dB}$ charakteryzował się karabinek AKM. Dźwięk strzału odróżnia także indywidualne, niepowtarzalne brzmienie zależne od kalibru, rodzaju amunicji, długości i konstrukcji lufy oraz zastosowanych urządzeń wylotowych. Kolejne rodzaje broni: pistolet maszynowy PPSz i pistolet osobisty P-83 charakteryzowały się znacznie niższymi i bardzo zbliżonymi do siebie (pomimo znaczących różnic w wymiarach fizycznych) poziomami emisji dźwięku w okolicach $\mathrm{Lp}(\mathrm{A})=77,6 \mathrm{~dB}$ i $\mathrm{Lw}(\mathrm{A})=67,23 \mathrm{~dB}$ (wartości dla PPSz). Najniższą emisją dźwięku wykazał się pistolet P-83, stanowiąc odpowiednio $\mathrm{Lp}(\mathrm{A})=76,31 \mathrm{~dB}$ i $\mathrm{Lw}(\mathrm{A})=65,37 \mathrm{~dB}$. Powodami tak znaczących różnic są m.in. długości ruchu mechanizmów i technologie wykonania. Pistolety P-83 i PPSz są wykonane z elementów o znacznie wyższej sztywności w porównaniu z AKM złożonym ze stosunkowo cienkich elementów łatwiej wpadających w drgania, a tym samym mocniej emitujących fale dźwiękowe. Zarejestrowane wyniki przedstawione na rysunkach i oscylogramach wykazują znaczące i istotne różnice emitowanego dźwięku, pozwalając na rozróżnienie i identyfikację rodzaju, typu, a nawet poszczególnych egzemplarzy broni, co potwierdzają wstępnie przeprowadzone pomiary.

\section{Literatura}

[1] Przestępstwa przy użyciu broni, statystyka.policja.pl/st/wybrane-statystyki/bron/ bron-przestepstwa/ 50844, Przestepstwa-przy-uzyciu-broni.html.

[2] Longwic R., Maciąg P., Szydło K.: Metodyka pomiaru emisji hałasu w kabinach dźwigów osobowych, Logistyka, 6 (2014) 6809-6817.

[3] Bruel\&Kjaer: Pomiary dźwięków. Bruel\&Kjaer 2850, Naerum, Denmark 1988.

[4] Cempel C.: Wibroakustyka stosowana, PWN, Warszawa 1989.

[5] Sound Intensity - Brüel\&Kjaer Revision, September 1993.

[6] Lotko W., Maciąg P., Maciąg M.: Nowa metoda oceny hałasu maszyn i urządzeń, Materiały Konferencji Naukowo-Technicznej „Pojazd a środowisko”, Radom 1997.

[7] Sound Intensity Software BZ7205 User Manual Bruel\&Kjaer Sound and Vibration Measurement A/S, Naerum, Denmark 1998. 


\section{FIREARMS IDENTIFICATION BASED ON ACOUSTIC SIGNALS}

\section{Summary}

The article presents preliminary results of the analysis of acoustic signals emitted by selected types of weapons. The research result part presented in the paper applies to the phase of shotgun preparation. Acoustic measurements were carried out using the Bruel\&Kjaer 2260 Investigator sound analyzer together with the B\&K 3595 dual-microphone sound intensity probe and the DSO2902 digital broadband analyzer.

Keywords: noise emission, firearms type identification, acoustic signals measurements

DOI: $10.7862 / \mathrm{rm} .2018 .22$

Przestano do redakcji: 23.04 .2018

Przyjęto do druku: 20.06.2018 
